\title{
On Value Premium, Part I: The Existence
}

\author{
Chi Fung Ling ${ }^{1}$, Simon Gar Man Koo ${ }^{2}$ \\ ${ }^{1}$ Department of Industrial Engineering and Operations Research, Columbia University, New York, USA \\ ${ }^{2}$ Department of Mathematics and Computer Science, University of San Diego, San Diego, USA \\ E-mail:cl2981@columbia.edu,koo@sandiego.edu \\ Received August 28, 2011; revised September 14, 2011; accepted September 22, 2011
}

\begin{abstract}
A great deal of academic research provides solid evidence that value investing generated better returns than growth investing from the early 1970s to the mid-1990s. However, the relatively poor performance of value stocks in the late 1990s generated suspicion that value investing was failing. Such claims were invalidated by empirical research showing that value stocks' slump in this period was not caused by a change in fundamental patterns, but rather by investors’ overly-rosy expectations for new technology companies.
\end{abstract}

Keywords: Value Investing, Value Premium, Growth Stocks, Value Stocks, Beta, Downside Risk, Systematic Risk

\section{Introduction}

The foundation of value investing dates back to [1] in which Graham and Dodd argued that securities should be purchased if their market price is less than their intrinsic value. Since then, this trading strategy has received much attention from investors and academics alike. Basu [2] showed that stocks with low price-to-earnings ratios $(\mathrm{P} / \mathrm{E})$ tend to have higher subsequent average returns than stocks with high P/E. They called this return "the value premium”. Echoing the result of [2], Fama and French [3] and Lakonishok, Shleifer, and Vishny [4] provided empirical evidence that the returns of value investing don't follow the beta rule in the Capital Asset Pricing Model, sparking debate about the death of beta.

On the other hand, Chan, Hamao, and Lakonishok [5] showed that the value premium also existed in Japan's stock market. Fama and French [6] further confirmed that value stocks outperformed growth stocks in all major financial markets.

This academic work has had a tremendous impact on the investment industry. Not only has value investing been widely adopted by portfolio managers, but ratios like the book value to market value of equity (BV/MV) has also become an important indicator of managers' investment strategy orientation.

Given the significance of value investing, this paper will be surveying empirical academic evidence for value premium. Note that the late-1990s equity market performance has always been used as a forceful counterargument to the existence of value premium. We will, however, show that even if we include the late-1990s stocks' performance, value investing had still generated superior returns.

\section{Proof of the Existence of Value Premium}

\subsection{Evidence}

Using stocks' data from 1963 to 1990 from CRSP-COMUSTAT Fama and French [3] sorted stocks into 10 portfolios according to their Book Value/Market Value (BV/MV). They further split the top and bottom decile portfolios into equal halves. In Table 1, one can see that the top decile portfolios (10A and 10B) have the highest BV/MV and are termed the "value portfolios." Market generally deems that value portfolios are stocks with little (earnings) growth in the past and will continue such trend in the future. The bottom decile portfolios (1A and 1B) have the lowest BV/MV and are termed "glamour/growth portfolios." They have opposite properties to that of value portfolios. The stocks in each portfolio are equally weighted and the portfolio is reconstructed each year according to the stocks' BV/MV. The result is shown in Table 1, Panel A. One can see that the value portfolio (10B) generated an average monthly return of $1.83 \%$, compared to $0.3 \%$, for the glamour portfolio $(1 \mathrm{~A})$, making for a $1.53 \%$ spread. One can also notice that their betas are very close to each other (1.35 vs. 1.36), supporting the idea that systematic risk cannot be attributed to this spread. However, some other measures of risk have to be taken into account before 
Table 1. Excerpt from Fama and French (1992)—Properties of portfolios formed on Book-to-Market Equity (BE/ME) and Earnings-Price Ratio (E/P), 1963-1990.

\begin{tabular}{|c|c|c|c|c|c|c|c|c|c|c|c|c|c|}
\hline Portfolio & 0 & $1 \mathrm{~A}$ & $1 \mathrm{~B}$ & 2 & 3 & 4 & 5 & 6 & 7 & 8 & 9 & $10 \mathrm{~A}$ & $10 \mathrm{~B}$ \\
\hline & & \multicolumn{12}{|c|}{ Panel A: Stocks Sorted on Book-to-Market Equity (BE/ME) } \\
\hline Return & & 0.30 & 0.67 & 0.87 & 0.97 & 1.04 & 1.17 & 1.30 & 1.44 & 1.50 & 1.59 & 1.92 & 1.83 \\
\hline$\beta$ & & 1.36 & 1.34 & 1.32 & 1.30 & 1.28 & 1.27 & 1.27 & 1.27 & 1.27 & 1.29 & 1.33 & 1.35 \\
\hline $\ln (\mathrm{ME})$ & & 4.53 & 4.67 & 4.69 & 4.56 & 4.47 & 4.38 & 4.23 & 4.06 & 3.85 & 3.51 & 3.06 & 2.65 \\
\hline $\ln (\mathrm{BE} / \mathrm{ME})$ & & -2.22 & -1.51 & -1.09 & -0.75 & -0.51 & -0.32 & -0.14 & 0.03 & 0.21 & 0.42 & 0.66 & 1.02 \\
\hline $\ln (\mathrm{A} / \mathrm{ME})$ & & -1.24 & -0.79 & -0.40 & -0.05 & 0.20 & 0.40 & 0.56 & 0.71 & 0.91 & 1.12 & 1.35 & 1.75 \\
\hline $\ln (\mathrm{A} / \mathrm{BE})$ & & 0.94 & 0.71 & 0.68 & 0.70 & 0.71 & 0.71 & 0.70 & 0.68 & 0.70 & 0.70 & 0.70 & 0.73 \\
\hline E/P dummy & & 0.29 & 0.15 & 0.10 & 0.08 & 0.08 & 0.08 & 0.09 & 0.09 & 0.11 & 0.15 & 0.22 & 0.36 \\
\hline $\mathrm{E}(+) / \mathrm{P}$ & & 0.03 & 0.04 & 0.06 & 0.08 & 0.09 & 0.10 & 0.11 & 0.11 & 0.12 & 0.12 & 0.11 & 0.10 \\
\hline Firms & & 89 & 98 & 209 & 222 & 226 & 230 & 235 & 237 & 239 & 239 & 120 & 117 \\
\hline \multirow[t]{2}{*}{ Portfolio } & 0 & $1 \mathrm{~A}$ & $1 \mathrm{~B}$ & 2 & 3 & 4 & 5 & 6 & 7 & 8 & 9 & $10 \mathrm{~A}$ & $10 \mathrm{~B}$ \\
\hline & \multicolumn{13}{|c|}{ Panel B: Stocks Sorted on Earnings-Price Ratio (E/P) } \\
\hline Return & 1.46 & 1.04 & 0.93 & 0.94 & 1.03 & 1.18 & 1.22 & 1.33 & 1.42 & 1.46 & 1.57 & 1.74 & 1.72 \\
\hline$\beta$ & 1.47 & 1.40 & 1.35 & 1.31 & 1.28 & 1.26 & 1.25 & 1.26 & 1.24 & 1.23 & 1.24 & 1.28 & 1.31 \\
\hline $\ln (\mathrm{ME})$ & 2.48 & 3.64 & 4.33 & 4.61 & 4.64 & 4.63 & 4.58 & 4.49 & 4.37 & 4.28 & 4.07 & 3.82 & 3.52 \\
\hline $\ln (\mathrm{BE} / \mathrm{ME})$ & -0.10 & -0.76 & -0.91 & -0.79 & -0.61 & -0.47 & -0.33 & -0.21 & -0.08 & 0.02 & 0.15 & 0.26 & 0.40 \\
\hline $\ln (\mathrm{A} / \mathrm{ME})$ & 0.90 & -0.05 & -0.27 & -0.16 & 0.03 & 0.18 & 0.31 & 0.44 & 0.58 & 0.70 & 0.85 & 1.01 & 1.25 \\
\hline $\ln (\mathrm{A} / \mathrm{BE})$ & 0.99 & 0.70 & 0.63 & 0.63 & 0.64 & 0.65 & 0.64 & 0.65 & 0.66 & 0.68 & 0.71 & 0.75 & 0.86 \\
\hline E/P dummy & 1.00 & 0.00 & 0.00 & 0.00 & 0.00 & 0.00 & 0.00 & 0.00 & 0.00 & 0.00 & 0.00 & 0.00 & 0.00 \\
\hline $\mathrm{E}(+) / \mathrm{P}$ & 0.00 & 0.01 & 0.03 & 0.05 & 0.06 & 0.08 & 0.09 & 0.11 & 0.12 & 0.14 & 0.16 & 0.20 & 0.28 \\
\hline Firms & 355 & 88 & 90 & 182 & 190 & 193 & 196 & 194 & 197 & 195 & 195 & 95 & 91 \\
\hline
\end{tabular}

At the end of each year $t-1,12$ portfolios are formed on the basis of ranked values of BE/ME or E/P. Portfolios 2 - 9 cover deciles of the ranking variables. The bottom and top 2 portfolios (1A, 1B, 10A, and 10B) split the bottom and top deciles in half. For E/P, there are 13 portfolios; portfolio 0 is stocks with negative $\mathrm{E} / \mathrm{P}$. Since BE/ME and E/P are not strongly related to the exchange listing, their portfolio breakpoints are determined on the basis of the ranked values of the variables for all stocks that satisfy the CRSP-COMPUSTAT data requirements. BE is the book value of common equity plus balance-sheet deferred taxes, $\mathrm{A}$ is total book assets, and $\mathrm{E}$ is earnings (income before extraordinary items, plus income-statement deferred taxes, minus preferred dividends). BE, A, and $\mathrm{E}$ are for each firm's latest fiscal year ending in calendar year $t-1$. The accounting ratios are measured using market equity ME in December of year $t-1$. Firm size $\ln (\mathrm{ME})$ is measured in June of year $t+1$, and then reform the portfolios at the end of year $t$. Return is the time-series average of the monthly equal-weighted portfolio returns (in percent). $\ln (\mathrm{ME}), \ln (\mathrm{BE} / \mathrm{ME}), \ln (\mathrm{A} / \mathrm{ME}), \ln (\mathrm{A} / \mathrm{BE}), \mathrm{E}(+) / \mathrm{P}$, and $\mathrm{E} / \mathrm{P}$ dummy are the time-series averages of the monthly average values of these variables in each portfolio. Since the E/P dummy is 0 when earnings are positive, and 1 when earnings are negative, E/P dummy gives the average proportion of stocks with negative earnings in each portfolio. $\beta$ is the time-series average of the monthly portfolio $\beta$ s. Stocks are assigned the post-ranking $\beta$ of the size$\beta$ portfolio they are in at the end of June of year $t$ (Table É). These individual-firm $\beta \mathrm{s}$ are averages to compute the monthly $\beta \mathrm{s}$ for each portfolio for July of year $t$ to June of year $t+1$. Firms is the average number of stocks in the portfolio each month.

we can determine conclusively that value stocks are not fundamentally riskier. Notice that the logarithm of MV for the value portfolio is 2.65 , compared to 4.53 for the glamour portfolio. This indicates the differences in sizes of the portfolios' market equity. According to [7], the stock of a small firm will always have a premium compared to that of a big firm, and this may contribute to spread.

Echoing the results of [3], Lakonishok, Shleifer, and Vishny [4] conducted similar empirical research using data from 1968 to 1989, and the results are shown in Table 2, Panel A. Instead of re-forming the portfolios each year, they used a buy-and-hold strategy: after constructing a portfolio, it is held for five years, and the average return is calculated annually. The goal of doing that is to evaluate the return of value investment in long term. One can see that the average annual return ("AR" in the table) of the value portfolio is $19.8 \%$ compared to $9.3 \%$ of the glamour portfolio, a $10.5 \%$ spread. To take the factor of size into account, the average annual sized-adjusted return ("SAAR") is also included in this table. After adjusting for size, the superiority of the value portfolio's returns persists even though the gap is now smaller: its SAAR is $3.5 \%$, compared to $-4.3 \%$ for the glamour portfolio, a $7.8 \%$ spread. This shows that part of the spread may be attributed to the size of equity.

Another proof came from [3] in which they compared the average monthly return of only large cap stocks. Again, they ranked stocks according to their BV/MV within this large-cap criterion and created 10 portfolios. The return of each portfolio is shown in Table $\mathbf{3}$ under the row 
Table 2. Excerpt from Lakonishok, Shleifer, and Vishny (1994)—Returns for decile portfolios based on one-dimensional classificiations by various measures of value, 1968-1989.

\begin{tabular}{|c|c|c|c|c|c|c|c|c|c|c|}
\hline & Glamour & & & & & & & & & Value \\
\hline & 1 & 2 & 3 & 4 & 5 & 6 & 7 & 8 & 9 & 10 \\
\hline & \multicolumn{10}{|c|}{ Panel A: B/M } \\
\hline$R_{1}$ & 0.0110 & 0.117 & 0.135 & 0.123 & 0.131 & 0.154 & 0.154 & 0.170 & 0.183 & 0.173 \\
\hline$R_{2}$ & 0.079 & 0.107 & 0.140 & 0.145 & 0.153 & 0.156 & 0.169 & 0.164 & 0.182 & 0.188 \\
\hline$R_{3}$ & 0.107 & 0.132 & 0.155 & 0.167 & 0.165 & 0.172 & 0.191 & 0.207 & 0.196 & 0.204 \\
\hline$R_{4}$ & 0.081 & 0.133 & 0.136 & 0.160 & 0.170 & 0.169 & 0.188 & 0.204 & 0.213 & 0.207 \\
\hline$R_{5}$ & 0.088 & 0.137 & 0.163 & 0.175 & 0.171 & 0.176 & 0.216 & 0.201 & 0.206 & 0.215 \\
\hline$A R$ & 0.093 & 0.125 & 0.146 & 0.154 & 0.158 & 0.166 & 0.184 & 0.189 & 0.196 & 0.198 \\
\hline$C R_{5}$ & 0.560 & 0.802 & 0.973 & 1.045 & 1.082 & 1.152 & 1.320 & 1.375 & 1.449 & 1.462 \\
\hline \multirow[t]{2}{*}{ SAAR } & -0.043 & -0.020 & -0.003 & 0.004 & 0.006 & 0.012 & 0.024 & 0.028 & 0.033 & 0.035 \\
\hline & \multicolumn{10}{|c|}{ Panel B: C/P } \\
\hline$R_{1}$ & 0.084 & 0.124 & 0.140 & 0.140 & 0.153 & 0.148 & 0.157 & 0.178 & 0.183 & 0.183 \\
\hline$R_{2}$ & 0.067 & 0.108 & 0.126 & 0.153 & 0.156 & 0.170 & 0.177 & 0.180 & 0.183 & 0.190 \\
\hline$R_{3}$ & 0.096 & 0.133 & 0.153 & 0.172 & 0.170 & 0.191 & 0.191 & 0.202 & 0.193 & 0.204 \\
\hline$R_{4}$ & 0.098 & 0.111 & 0.146 & 0.159 & 0.166 & 0.172 & 0.182 & 0.192 & 0.223 & 0.218 \\
\hline$R_{5}$ & 0.108 & 0.134 & 0.161 & 0.162 & 0.187 & 0.177 & 0.191 & 0.209 & 0.212 & 0.208 \\
\hline$A R$ & 0.091 & 0.122 & 0.145 & 0.157 & 0.166 & 0.171 & 0.180 & 0.192 & 0.199 & 0.201 \\
\hline$C R_{5}$ & 0.543 & 0.779 & 0.969 & 1.074 & 1.158 & 1.206 & 1.283 & 1.406 & 1.476 & 1.494 \\
\hline \multirow[t]{2}{*}{ SAAR } & -0.049 & -0.025 & -0.006 & 0.005 & 0.013 & 0.019 & 0.025 & 0.034 & 0.037 & 0.039 \\
\hline & \multicolumn{10}{|c|}{ Panel C: E/P } \\
\hline$R_{1}$ & 0.123 & 0.125 & 0.140 & 0.130 & 0.135 & 0.156 & 0.170 & 0.180 & 0.193 & 0.162 \\
\hline$R_{2}$ & 0.101 & 0.113 & 0.124 & 0.143 & 0.167 & 0.164 & 0.180 & 0.185 & 0.183 & 0.174 \\
\hline$R_{3}$ & 0.118 & 0.138 & 0.157 & 0.171 & 0.171 & 0.191 & 0.198 & 0.188 & 0.188 & 0.195 \\
\hline$R_{4}$ & 0.111 & 0.124 & 0.145 & 0.151 & 0.157 & 0.159 & 0.198 & 0.199 & 0.205 & 0.214 \\
\hline$R_{5}$ & 0.119 & 0.129 & 0.151 & 0.167 & 0.171 & 0.168 & 0.196 & 0.201 & 0.211 & 0.207 \\
\hline$A R$ & 0.114 & 0.126 & 0.143 & 0.152 & 0.160 & 0.167 & 0.188 & 0.191 & 0.196 & 0.190 \\
\hline$C R_{5}$ & 0.717 & 0.808 & 0.953 & 1.031 & 1.102 & 1.168 & 1.370 & 1.393 & 1.446 & 1.388 \\
\hline \multirow[t]{4}{*}{ SAAR } & -0.035 & -0.024 & -0.009 & -0.001 & 0.005 & 0.013 & 0.026 & 0.026 & 0.029 & 0.019 \\
\hline & \multicolumn{10}{|c|}{ Panel D: GS } \\
\hline & Value & & & & & & & & & Glamour \\
\hline & 1 & 2 & 3 & 4 & 5 & 6 & 7 & 8 & 9 & 10 \\
\hline$R_{1}$ & 0.187 & 0.183 & 0.164 & 0.169 & 0.162 & 0.157 & 0.159 & 0.164 & 0.142 & 0.114 \\
\hline$R_{2}$ & 0.181 & 0.180 & 0.186 & 0.169 & 0.166 & 0.162 & 0.152 & 0.157 & 0.147 & 0.131 \\
\hline$R_{3}$ & 0.204 & 0.206 & 0.194 & 0.186 & 0.181 & 0.180 & 0.168 & 0.178 & 0.157 & 0.138 \\
\hline$R_{4}$ & 0.205 & 0.193 & 0.201 & 0.190 & 0.181 & 0.174 & 0.160 & 0.153 & 0.167 & 0.126 \\
\hline$R_{5}$ & 0.197 & 0.213 & 0.194 & 0.199 & 0.168 & 0.184 & 0.185 & 0.168 & 0.163 & 0.125 \\
\hline$A R$ & 0.195 & 0.195 & 0.188 & 0.183 & 0.171 & 0.171 & 0.165 & 0.164 & 0.155 & 0.127 \\
\hline$C R_{5}$ & 1.434 & 1.435 & 1.364 & 1.314 & 1.205 & 1.206 & 1.144 & 1.136 & 1.057 & 0.818 \\
\hline SAAR & 0.022 & 0.027 & 0.025 & 0.024 & 0.015 & 0.015 & 0.008 & 0.008 & 0.000 & -0.024 \\
\hline
\end{tabular}

At the end of each April between 1968 and 1989, 10-decile portfolios are formed in ascending order based on B/M, C/P, E/P, and GS. B/M is the ratio of book value of equity to market value of equity; $\mathrm{C} / \mathrm{P}$ is the ratio of cash flow to market value of equity; E/P is the ratio of earnings to market value of equity, and GS refers to preformation 5-year average growth rate of sales. The returns presented in the table are averages over all formation periods. $R_{t}$ is the average return in year $t$ after formation, $t=1, \cdots, 5$. AR is the average annual return over 5 postformation years. $C R_{5}$ is the compounded 5 -year return assuming annual rebalancing. SAAR is the average annual size-adjusted return computed over 5 postformation years. The glamour portfolio refers to the decile portfolio containing stocks ranking lowest on $\mathrm{B} / \mathrm{M}, \mathrm{C} / \mathrm{P}$, or $\mathrm{E} / \mathrm{P}$, or highest on $\mathrm{GS}$. The value portfolio refers to the decile portfolio containing stocks ranking highest on $\mathrm{B} / \mathrm{M}$, $\mathrm{C} / \mathrm{P}$, or $\mathrm{E} / \mathrm{P}$, or lowest on GS. 
Table 3. Excerpt from Fama and French (1992)_Average monthly returns on portfolios formed on size and Book-to-Market; Stocks Sorted by ME (Down) and then BE/ME (Across), 1963-1990.

\begin{tabular}{|c|c|c|c|c|c|c|c|c|c|c|c|}
\hline \multicolumn{12}{|c|}{ Book-to-Market Portfolios } \\
\hline & All & Low & 2 & 3 & 4 & 5 & 6 & 7 & 8 & 9 & High \\
\hline All & 1.23 & 0.64 & 0.98 & 1.06 & 1.17 & 1.24 & 1.26 & 1.39 & 1.40 & 1.50 & 1.63 \\
\hline Small-ME & 1.47 & 0.7 & 1.14 & 1.20 & 1.43 & 1.56 & 1.51 & 1.70 & 1.71 & 1.82 & 1.92 \\
\hline ME-2 & 1.22 & 0.43 & 1.05 & 0.96 & 1.19 & 1.33 & 1.19 & 1.58 & 1.28 & 1.43 & 1.79 \\
\hline ME-3 & 1.22 & 0.56 & 0.88 & 1.23 & 0.95 & 1.36 & 1.30 & 1.30 & 1.40 & 1.54 & 1.60 \\
\hline ME-4 & 1.19 & 0.39 & 0.72 & 1.06 & 1.36 & 1.13 & 1.21 & 1.34 & 1.59 & 1.51 & 1.47 \\
\hline ME-5 & 1.24 & 0.88 & 0.65 & 1.08 & 1.47 & 1.13 & 1.43 & 1.44 & 1.26 & 1.52 & 1.49 \\
\hline ME-6 & 1.15 & 0.7 & 0.98 & 1.14 & 1.23 & 0.94 & 1.27 & 1.19 & 1.19 & 1.24 & 1.50 \\
\hline ME-7 & 1.07 & 0.95 & 1.00 & 0.99 & 0.83 & 0.99 & 1.13 & 0.99 & 1.16 & 1.10 & 1.47 \\
\hline ME-8 & 1.08 & 0.66 & 1.13 & 0.91 & 0.95 & 0.99 & 1.01 & 1.15 & 1.05 & 1.29 & 1.55 \\
\hline ME-9 & 0.95 & 0.44 & 0.89 & 0.92 & 1.00 & 1.05 & 0.93 & 0.82 & 1.11 & 1.04 & 1.22 \\
\hline Large-ME & 0.89 & 0.93 & 0.88 & 0.84 & 0.71 & 0.79 & 0.83 & 0.81 & 0.96 & 0.97 & 1.18 \\
\hline
\end{tabular}

In June of each year $t$, the NYSE, AMEX, and NASDAQ stocks that meet the CRSP-COMPUSTAT data requirements are allocated to 10 size portfolios using the NYSE size (ME) breakpoints. The NYSE, AMEX, and NASDAQ stocks in each size decile then sorted into 10 BE/ME portfolios using the book-to-market ratios for year $t-1$, over the market equity for December of year $t-1$. The equal-weighted monthly portfolio returns are then calculated for July of year $t$ to June of year $t+1$. Average monthly return is the time-series average of the monthly equal-weighted portfolio returns (in percent). The All column shows average returns for equal-weighted size decile portfolios. The All row shows average returns for equal-weighted portfolios of the stocks in each BE/ME group.

LARGE-ME. Notice that the average monthly return for the value stocks is $1.18 \%$ compared to $0.89 \%$ for the glamour stocks, a $0.29 \%$ spread. The spread still exists but it is less substantial. Combining the studies above lead us to conclude that part of the spread may be attribute to the size of equity. But the spread still exists even if we take the size factor into account and this could be due to the value premium.

Research was also conducted to see if another measure could be used to create a similar value-growth spread. For example, in Table 1, Panel B and Table 2, Panel C, Earnings to Price ratio was used to rank stocks instead of BV/MV. Although the spread still existed (1.46\% vs. $1.72 \%$ and $11.4 \%$ vs. $19 \%$ ), it was less substantial than with BV/MV. According to [4], this narrower spread may be caused by the noisy nature of earnings. For example, a low E/P may reflect a growth stock; people expect it to have high earnings in the future. However, a security that is not a growth stock can also have a low E/P caused by its temporarily depressed earnings. If we use $\mathrm{E} / \mathrm{P}$ as an indicator, we will include the latter stocks as well.

Not all ratios have such a noisy nature. Some valuation ratios can be used to yield higher returns than using BV/MV. One such example is cash flow to price ratio (CF/P). The results from the application of this measure are shown in Table 2, Panel B. Notice that the annual return of the glamour portfolio is $9.1 \%$ compared to $20.1 \%$ of the value portfolio. This spread of $11 \%$ is slightly larger than when $\mathrm{BV} / \mathrm{MV}$ was used as a measure.

Lakonishok, Shleifer, and Vishny [4] also argued that if the correlations between different signals are not high, one can use several measures to generate even better returns. Indeed, Chan and Lakonishok [8] used robust regression methods to determine whether a stock is value or growth. They created cross-sectional models to predict future returns from BV/MV, CF/P, E/P, and sales-to-price $(\mathrm{S} / \mathrm{P})$ ratios. Then they used the estimated slope coefficients to determine weights to be applied to each fundamental variable, thus arriving at the overall indicator. In Table 4 stocks are separated into 10 deciles and the return is recorded for each portfolio. We can see that from 1979 through 2001, the mean return on the "deep value" portfolio (decile 10) for large-cap stocks (Panel A) exceeded the return on the Russell 1000 Value Index over the same period by 5\% (Panel A2). Similarly, when applied to small-caps for the same period (Panel B2), the strategy averaged a better return for the deep value portfolio (22.8\%) than for the Russell 2000 Value benchmark (16.0\%). This gives evidence that the use of multiple measures in the composite indicator boosts the performance of the value strategy.

Chan and Lakonishok [8] also tested the composite strategy on securities from other countries. Using the same indicators, they chose the largest-cap stocks in the MSCI EAFE Index (Europe/Australasia/Far East) of developed non-U.S. countries. They then calculated buy-and-hold returns in local currency terms for the year following the formation of the portfolios. After that, they aggregated returns across countries based on the EAFE country weights. The results shown in Table 5 echoed those from the U.S market. With the exception of 1998 and 1999, value stocks consistently outperformed growth stocks, and the aver- 
Table 4. Excerpt from Chan and Lakonishok (2004) yearly and geometric returns to value and growth strategies with refined definitions, 1969-2001.

\begin{tabular}{|c|c|c|c|c|c|c|c|}
\hline \multicolumn{8}{|c|}{ A. Large-cap stocks } \\
\hline & \multicolumn{4}{|c|}{ Portfolio } & \multirow{2}{*}{$\begin{array}{l}\text { Russell } 1000 \\
\text { Value Return }\end{array}$} & \multirow{2}{*}{$\begin{array}{c}\text { S\&P } 500 \\
\text { Return }\end{array}$} & \multirow{2}{*}{$\begin{array}{l}\text { (Deciles 9, 10) } \\
\text {-(Deciles 1, 2) }\end{array}$} \\
\hline Year & 1 (glamour) & 2 & 9 & 10(value) & & & \\
\hline \multicolumn{8}{|l|}{ 1. By year } \\
\hline 1969 & $-1.5 \%$ & $-8.3 \%$ & $-21.0 \%$ & $-21.6 \%$ & NA & $-8.5 \%$ & $-16.4 \mathrm{pps}$ \\
\hline 1970 & -16.6 & -15.7 & 9.5 & 2.2 & NA & 4.0 & 22.0 \\
\hline 1971 & 37.2 & 28.4 & 14.8 & 12.0 & NA & 14.3 & -19.4 \\
\hline 1972 & 23.8 & 11.6 & 11.3 & 10.8 & NA & 19.0 & -6.7 \\
\hline 1973 & -32.2 & -26.2 & -10.2 & -21.2 & NA & -14.7 & 13.5 \\
\hline 1974 & -42.1 & -38.6 & -18.6 & -14.3 & NA & -26.5 & 23.9 \\
\hline 1975 & 19.3 & 38.5 & 62.9 & 61.2 & NA & 37.2 & 33.1 \\
\hline 1976 & 6.9 & 21.0 & 50.1 & 54.7 & NA & 23.8 & 38.5 \\
\hline 1977 & -2.4 & -4.7 & 6.2 & 7.2 & NA & -7.2 & 10.2 \\
\hline 1978 & 11.6 & 7.9 & 12.7 & 16.8 & NA & 6.6 & 5.0 \\
\hline 1979 & 41.7 & 28.9 & 34.2 & 30.7 & $20.6 \%$ & 18.4 & -2.8 \\
\hline 1980 & 68.3 & 48.3 & 16.8 & 22.9 & 24.4 & 32.4 & -38.5 \\
\hline 1981 & -16.3 & -8.0 & 10.0 & 14.1 & 1.3 & -4.9 & 24.2 \\
\hline 1982 & 9.2 & 14.7 & 24.8 & 29.8 & 20.0 & 21.4 & 21.7 \\
\hline 1983 & 16.3 & 16.7 & 31.5 & 39.0 & 28.3 & 22.5 & 18.7 \\
\hline 1984 & -22.5 & -5.1 & 11.9 & 15.5 & 10.1 & 6.3 & 27.4 \\
\hline 1985 & 22.8 & 35.9 & 35.5 & 38.3 & 31.5 & 32.2 & 7.6 \\
\hline 1986 & 12.6 & 8.6 & 21.9 & 21.6 & 20.0 & 18.5 & 11.2 \\
\hline 1987 & -5.4 & 5.4 & 1.2 & -3.1 & 0.5 & 5.2 & -1.0 \\
\hline 1988 & 6.9 & 9.4 & 33.2 & 32.7 & 23.2 & 16.8 & 24.8 \\
\hline 1989 & 32.6 & 27.3 & 19.1 & 19.5 & 25.2 & 31.5 & -10.7 \\
\hline 1990 & -5.7 & -8.7 & -15.6 & -21.8 & -8.1 & -3.2 & -11.5 \\
\hline 1991 & 62.0 & 34.4 & 47.5 & 55.9 & 24.6 & 30.6 & 3.5 \\
\hline 1992 & -8.0 & 3.2 & 24.0 & 26.1 & 13.8 & 7.7 & 27.5 \\
\hline 1993 & 16.6 & 12.9 & 12.6 & 20.3 & 18.1 & 10.0 & 1.7 \\
\hline 1994 & -13.6 & -0.1 & -0.7 & 3.1 & -2.0 & 1.3 & 8.0 \\
\hline 1995 & 29.8 & 21.7 & 40.5 & 39.0 & 38.4 & 37.4 & 14.0 \\
\hline 1996 & 12.0 & 14.5 & 22.4 & 21.5 & 21.6 & 23.1 & 8.7 \\
\hline 1997 & 0.3 & 19.8 & 33.1 & 34.4 & 35.2 & 33.4 & 23.7 \\
\hline 1998 & 19.7 & 12.8 & 6.2 & -2.0 & 15.6 & 28.6 & -14.1 \\
\hline 1999 & 62.3 & 24.7 & 7.5 & 12.3 & 7.4 & 21.0 & -33.6 \\
\hline 2000 & -34.9 & -18.6 & 14.4 & 21.6 & 7.0 & -9.1 & 44.7 \\
\hline 2001 & -40.0 & -26.1 & 16.8 & 26.2 & -5.6 & -11.9 & 54.5 \\
\hline \multicolumn{8}{|c|}{ 2. By group of years } \\
\hline 1969-2001 & $4.5 \%$ & $6.7 \%$ & $15.6 \%$ & $16.4 \%$ & NA & $11.4 \%$ & $10.4 \mathrm{pps}$ \\
\hline $1979-2001$ & 7.9 & 10.4 & 18.6 & 20.4 & $15.4 \%$ & 15.1 & 10.4 \\
\hline $1990-2001$ & 3.8 & 6.0 & 16.1 & 18.0 & 12.9 & 12.9 & 12.2 \\
\hline
\end{tabular}




\begin{tabular}{|c|c|c|c|c|c|c|c|}
\hline & \multicolumn{3}{|c|}{ Portfolio } & & \multirow{2}{*}{$\begin{array}{l}\text { Russell } 2000 \\
\text { Value Return }\end{array}$} & \multirow{2}{*}{$\begin{array}{c}\text { Russell } 2000 \\
\text { Return }\end{array}$} & \multirow{2}{*}{$\begin{array}{l}\text { (Deciles 9, 10) } \\
\text {-(Deciles 1, 2) }\end{array}$} \\
\hline & 1 (glamour) & 2 & 9 & 10 (value) & & & \\
\hline \multicolumn{8}{|l|}{ 1. By Year } \\
\hline 1969 & $-30.2 \%$ & $-13.8 \%$ & $-20.5 \%$ & $-25.0 \%$ & NA & NA & -0.7 \\
\hline 1970 & -35.9 & -24.3 & -2.4 & 10.1 & NA & NA & 33.9 \\
\hline 1971 & 29.0 & 18.9 & 14.1 & 15.9 & NA & NA & -8.9 \\
\hline 1972 & 13.5 & -0.4 & 12.7 & 6.5 & NA & NA & 3.1 \\
\hline 1973 & -35.1 & -40.1 & -30.0 & -25.8 & NA & NA & 9.7 \\
\hline 1974 & -42.5 & -39.1 & -19.3 & -11.6 & NA & NA & 25.3 \\
\hline 1975 & 46.4 & 50.6 & 69.8 & 62.1 & NA & NA & 17.4 \\
\hline 1976 & 28.0 & 41.8 & 54.9 & 49.9 & NA & NA & 17.5 \\
\hline 1977 & 9.0 & 13.6 & 17.0 & 18.4 & NA & NA & 6.4 \\
\hline 1978 & 18.3 & 21.7 & 19.2 & 19.8 & NA & NA & -0.5 \\
\hline 1979 & 56.1 & 59.8 & 28.0 & 32.6 & $35.4 \%$ & $43.1 \%$ & -27.7 \\
\hline 1980 & 65.3 & 57.6 & 23.2 & 28.6 & 25.4 & 38.6 & -35.5 \\
\hline 1981 & -38.5 & -16.8 & 20.0 & 25.7 & 14.9 & 2.0 & 50.5 \\
\hline 1982 & 5.3 & 13.2 & 33.5 & 44.7 & 28.5 & 24.9 & 29.9 \\
\hline 1983 & 3.4 & 16.2 & 41.3 & 52.3 & 38.6 & 29.1 & 37.0 \\
\hline 1984 & -30.0 & -19.7 & 15.0 & 19.3 & 2.3 & -7.3 & 42.0 \\
\hline 1985 & 23.2 & 29.6 & 41.0 & 41.0 & 31.0 & 31.1 & 14.6 \\
\hline 1986 & -0.9 & 7.0 & 13.7 & 24.7 & 7.4 & 5.7 & 16.1 \\
\hline 1987 & -18.7 & -10.3 & -6.1 & 4.0 & -7.1 & -8.8 & 13.5 \\
\hline 1988 & -5.2 & 13.3 & 39.2 & 37.2 & 29.5 & 24.9 & 34.1 \\
\hline 1989 & 26.3 & 19.3 & 17.5 & 12.8 & 12.4 & 16.2 & -7.7 \\
\hline 1990 & -24.0 & -14.6 & -19.3 & -22.0 & -21.8 & -19.5 & -1.4 \\
\hline 1991 & 51.0 & 38.8 & 48.4 & 46.0 & 41.7 & 46.1 & 2.3 \\
\hline 1992 & -21.3 & -2.2 & 28.0 & 29.4 & 29.1 & 18.4 & 40.4 \\
\hline 1993 & -5.9 & 10.0 & 18.5 & 18.3 & 23.8 & 18.9 & 16.3 \\
\hline 1994 & -35.2 & -11.3 & 2.8 & 4.0 & -1.6 & -1.8 & 26.7 \\
\hline 1995 & 27.8 & 35.4 & 32.9 & 32.0 & 25.8 & 28.4 & 0.9 \\
\hline 1996 & -7.5 & 13.9 & 29.3 & 28.6 & 21.4 & 16.5 & 25.7 \\
\hline 1997 & -11.7 & 3.6 & 40.1 & 39.3 & 31.8 & 22.4 & 43.7 \\
\hline 1998 & -6.5 & 1.2 & -0.7 & -2.4 & -6.5 & -2.5 & 1.1 \\
\hline 1999 & 52.8 & 26.2 & 14.3 & 6.4 & -1.5 & 21.3 & -29.1 \\
\hline 2000 & -38.9 & -23.8 & 5.7 & 12.5 & 22.8 & -3.0 & 40.5 \\
\hline 2001 & -7.8 & -13.5 & 40.9 & 41.3 & 14.0 & 2.5 & 51.7 \\
\hline \multicolumn{8}{|c|}{ 2. By group of years } \\
\hline 1969-2001 & $-2.8 \%$ & $4.8 \%$ & $16.6 \%$ & $18.3 \%$ & NA & NA & $16.5 \mathrm{pps}$ \\
\hline $1979-2001$ & -1.8 & 7.8 & 20.8 & 22.8 & $16.0 \%$ & $13.8 \%$ & 18.8 \\
\hline $1990-2001$ & -6.2 & 3.6 & 18.4 & 17.7 & 13.4 & 11.0 & 19.4 \\
\hline
\end{tabular}


Table 5. Excerpt from Chan and Lakonishok (2004) - Yearly and geometric mean returns to value and growth strategies with refined definitions in EAFE Markets, 1989-2001.

\begin{tabular}{|c|c|c|c|c|c|c|}
\hline \multicolumn{5}{|c|}{ Portfolio } & \multirow{2}{*}{$\begin{array}{c}\text { EAFE Free } \\
\text { Return }\end{array}$} & \multirow{2}{*}{$\begin{array}{l}\text { (Deciles 9, 10) } \\
\text {-(Deciles } 1,2)\end{array}$} \\
\hline Year & 1 (glamour) & 2 & 9 & 10 (value) & & \\
\hline 1989 & $35.6 \%$ & $33.5 \%$ & $48.9 \%$ & $53.2 \%$ & $21.5 \%$ & 16.5 \\
\hline 1990 & -35.4 & -33.6 & -24.8 & -23.6 & -29.9 & 10.3 \\
\hline 1991 & -5.5 & 0.6 & 8.2 & 15.8 & 8.6 & 14.5 \\
\hline 1992 & -18.4 & -15.5 & -4.6 & 2.0 & -6.3 & 15.7 \\
\hline 1993 & 13.7 & 17.5 & 41.5 & 49.3 & 29.3 & 29.8 \\
\hline 1994 & -4.8 & -1.7 & 0.3 & 3.2 & -2.1 & 5.0 \\
\hline 1995 & 1.5 & 1.1 & 1.4 & 5.8 & 9.6 & 2.3 \\
\hline 1996 & 0.9 & 10.2 & 10.3 & 12.4 & 11.4 & 5.8 \\
\hline 1997 & -3.3 & -4.5 & 3.5 & 3.2 & 13.2 & 7.3 \\
\hline 1998 & 12.9 & 8.9 & 6.3 & -5.9 & 12.4 & -4.8 \\
\hline 1999 & 84.7 & 46.7 & 26.9 & 26.5 & 33.2 & -39.0 \\
\hline 2000 & -27.8 & -21.3 & 8.1 & 15.8 & -7.3 & 36.5 \\
\hline 2001 & -49.5 & -34.2 & 0.7 & 11.5 & -16.3 & 47.9 \\
\hline Period Mean & -4.5 & -2.0 & 8.2 & 12.3 & 4.5 & 13.5 \\
\hline
\end{tabular}

age annual spread was $13.5 \%$ between 1989 and 2001. The evidence indicates that value investing and the composite strategy worked in both U.S and non-U.S. markets.

In addition to the composite strategy, other indicators have been used for selecting growth and value stocks. For example, Asness [9] and Daniel and Titman [10] studied the correlation between the value effect and past returns (price momentum). Chan, Lakonishok, and Sougiannis [11] incorporated intangible assets, and found that doing so improved the performance of the value approach. Piotroski [12] used various data from financial statements to identify more sharply successful value stocks. The blending of various indicators can often yield a higher return than using a single indicator.

\subsection{Value Investing Failing?}

Although the period from 1960 to 1990 provided solid support for the concept of value investing, returns in the late 1990s suggested its benefit may have been diminished. In Table 6, Chan and Lakonishok [8] show benchmark indexes from the Frank Russell Company that capture the performance of various equity asset classes. We see from the Russell 3000 column that growth stocks outperformed value stocks from 1996-1999, and the same was true for the Russell Top 200, Rusell Mid-Cap, Russell 1000 and Russell 2000. In fact, in the Russell 3000, the geometric return from growth stocks in 1996-1999 was a lot higher than value stocks (29.76\% vs. $18.69 \%)$. This information made analysts and journalists begin to question whether a new paradigm of equity investment was emerging.

Chan, Karceski, and Lakonishok [13] sorted out the competing explanations. Advocates for the value premium believe investors often incorrectly use past performance to predict future performance, making growth stocks overpriced and value stocks underpriced (extrapolation bias). Therefore, if the value premium had vanished (or if value stocks were underperforming), then perhaps past performance could now reliably predict future performance. If so, growth stocks (low BV/MV) should now have stronger subsequent earnings growth than value stocks (high BV/MV).

The authors then examined whether growth stocks' sizzling performances in the late 1990s could be explained by a sequence of unanticipated positive shocks to cash flows. Table 7 shows the results. Because the main contrast came from the largest-cap stocks, they categorized the largest 200 stocks as either value and glamour, according to BV/MV. We can see in Panel A that at the beginning of 1999, the price-to-earnings (P/I) ratio for growth stocks stood at 17.6 , and the widening of the $\mathrm{P} / \mathrm{I}$ ratio for growth stocks compared to value stocks was exacerbated later in 1999 and in the first quarter of 2000. However, the realized return of the growth stocks didn't match their high P/I. As shown in Panel B, there wasn't a big difference between the growth of operating income before depreciation between large-cap growth and value stocks. Therefore, past performance remained a poor indicator of future performance and investors still possessed an extrapolation bias when it came to growth stocks.

Chan, Karceski, and Lakonishok [13] further argued 
Table 6. Excerpt from Chan and Lakonishok (2004)—Annual returns for value and growth indexes, 1979-2002.

\begin{tabular}{|c|c|c|c|c|c|c|c|c|c|c|c|}
\hline \multirow[b]{2}{*}{ Year } & \multicolumn{2}{|c|}{ Russell 3000} & \multicolumn{2}{|c|}{ Russell Top 200} & \multicolumn{2}{|c|}{ Russell Mid-Cap } & \multicolumn{2}{|c|}{ Russell 1000} & \multicolumn{2}{|c|}{ Russell 2000} & \multirow{2}{*}{$\begin{array}{c}\text { S\&P500 } \\
\text { Index }\end{array}$} \\
\hline & Growth & Value & Growth & Value & Growth & Value & Growth & Value & Growth & Value & \\
\hline 1979 & $26.20 \%$ & $21.85 \%$ & NA & NA & NA & NA & $23.91 \%$ & $20.55 \%$ & $50.83 \%$ & $35.38 \%$ & $18.44 \%$ \\
\hline 1980 & 40.74 & 24.52 & NA & NA & NA & NA & 39.57 & 24.41 & 52.26 & 25.39 & 32.42 \\
\hline 1981 & -11.09 & 2.49 & NA & NA & NA & NA & -11.31 & 1.26 & -9.24 & 14.85 & -4.91 \\
\hline 1983 & 16.29 & 29.24 & NA & NA & NA & NA & 15.98 & 28.29 & 20.13 & 38.64 & 22.51 \\
\hline 1984 & -2.75 & 9.28 & NA & NA & NA & NA & -0.95 & 10.10 & -15.83 & 2.27 & 6.27 \\
\hline 1985 & 32.69 & 31.48 & NA & NA & NA & NA & 32.85 & 31.51 & 30.97 & 31.01 & 32.16 \\
\hline 1986 & 14.25 & 18.78 & $13.99 \%$ & $21.44 \%$ & $17.55 \%$ & $17.87 \%$ & 15.36 & 19.98 & 3.58 & 7.41 & 18.47 \\
\hline 1987 & 3.92 & -0.13 & 6.45 & 2.20 & 2.76 & -2.19 & 5.31 & 0.50 & -10.48 & -7.11 & 5.23 \\
\hline 1988 & 12.00 & 23.63 & 10.88 & 22.02 & 12.92 & 24.61 & 11.27 & 23.16 & 20.37 & 29.47 & 16.81 \\
\hline 1989 & 34.68 & 24.22 & 37.68 & 26.66 & 31.48 & 22.70 & 35.92 & 25.19 & 20.17 & 12.43 & 31.49 \\
\hline 1990 & -1.31 & -8.85 & 1.37 & -3.67 & --5.13 & -16.09 & -0.26 & -8.08 & -17.41 & -21.77 & -3.17 \\
\hline 1991 & 41.66 & 25.41 & 39.41 & 18.16 & 47.03 & 37.92 & 41.16 & 24.61 & 51.19 & 41.70 & 30.55 \\
\hline 1992 & 5.22 & 14.90 & 3.89 & 9.07 & 8.71 & 21.68 & 5.00 & 13.81 & 7.77 & 29.14 & 7.67 \\
\hline 1993 & 3.69 & 18.65 & -0.07 & 19.76 & 11.19 & 15.62 & 2.90 & 18.12 & 13.36 & 23.84 & 9.99 \\
\hline 1994 & 2.20 & -1.95 & 4.85 & -1.90 & -2.17 & -2.13 & 2.66 & -1.99 & -2.43 & -1.55 & 1.31 \\
\hline 1995 & 36.57 & 37.03 & 38.65 & 40.03 & 33.98 & 34.93 & 37.19 & 38.35 & 31.04 & 25.75 & 37.43 \\
\hline 1996 & 21.88 & 21.60 & 25.57 & 22.31 & 17.48 & 20.26 & 23.12 & 21.63 & 11.26 & 21.37 & 23.07 \\
\hline 1997 & 28.74 & 34.83 & 33.73 & 35.47 & 22.54 & 34.37 & 30.49 & 35.18 & 12.95 & 31.78 & 33.36 \\
\hline 2000 & -22.42 & 8.02 & -24.51 & 2.31 & -11.75 & 19.19 & -22.43 & 7.02 & -22.44 & 22.82 & -9.11 \\
\hline 2001 & -19.63 & -4.33 & -20.50 & -8.80 & -20.16 & 2.33 & -20.42 & -5.59 & -9.24 & 14.02 & -11.88 \\
\hline 2002 & -28.04 & -15.18 & -27.98 & -18.02 & -27.41 & -9.65 & -27.89 & -15.52 & -30.26 & -11.43 & -22.10 \\
\hline \multicolumn{12}{|c|}{ Geometric Mean } \\
\hline 1996-1999 & 29.76 & 18.69 & 33.32 & 22.18 & 26.58 & 14.12 & 31.25 & 19.52 & 16.16 & 10.18 & 26.42 \\
\hline \multicolumn{12}{|c|}{ Geometric Mean } \\
\hline 1979-2002 & 11.57 & 13.99 & & & & & 11.84 & 13.93 & 8.94 & 14.74 & 13.25 \\
\hline \multicolumn{12}{|c|}{ Standard deviation } \\
\hline 1979-2002 & 20.71 & 14.05 & & & & & 20.84 & 14.16 & 23.83 & 17.40 & 16.42 \\
\hline \multicolumn{12}{|c|}{ Geometric mean } \\
\hline 1986-2002 & 9.73 & 11.78 & 10.42 & 11.82 & 10.19 & 12.21 & 10.18 & 11.9 & 5.12 & 10.92 & 11.50 \\
\hline \multicolumn{12}{|c|}{ Standard deviation } \\
\hline 1986-2002 & 21.83 & 15.04 & 23.15 & 15.79 & 21.77 & 16.10 & 22.27 & 15.27 & 22.13 & 18.01 & 17.59 \\
\hline \multicolumn{12}{|c|}{ Percentage of years } \\
\hline \multicolumn{12}{|l|}{ value exceeded } \\
\hline glamour & & 54 & & 53 & & 65 & & 50 & & 67 & \\
\hline $\mathrm{NA}=$ not availa & & & & & & & & & & & \\
\hline
\end{tabular}


Table 7. Excerpt from Chan, Karceski, and Lakonishok (2000)—Operating income before depreciation, 1970-1998.

\begin{tabular}{|c|c|c|c|c|c|c|}
\hline \multirow{2}{*}{ Year } & \multicolumn{3}{|c|}{ Growth } & \multicolumn{3}{|c|}{ Value } \\
\hline & Small & Medium & Large & Small & Medium & Large \\
\hline \multicolumn{7}{|c|}{ A. Price-to-income ratio } \\
\hline 1990 & 7.67 & 6.22 & 6.83 & 3.85 & 3.56 & 3.58 \\
\hline 1991 & 5.97 & 5.11 & 6.03 & 2.69 & 2.90 & 3.34 \\
\hline 1992 & 11.17 & 8.46 & 8.17 & 3.85 & 3.70 & 4.55 \\
\hline 1993 & 10.69 & 8.32 & 8.37 & 4.62 & 4.38 & 4.40 \\
\hline 1994 & 10.70 & 8.62 & 6.98 & 5.67 & 4.57 & 4.84 \\
\hline 1995 & 9.79 & 7.36 & 6.37 & 4.76 & 3.98 & 4.03 \\
\hline 1996 & 11.00 & 8.11 & 8.42 & 5.04 & 4.34 & 4.57 \\
\hline 1997 & 11.91 & 9.39 & 10.60 & 5.51 & 4.93 & 4.89 \\
\hline 1998 & 13.48 & 10.21 & 12.67 & 5.83 & 5.51 & 6.06 \\
\hline 1999 & 12.50 & 11.58 & 17.60 & 5.22 & 5.14 & 7.27 \\
\hline $1970-1998$ & 7.10 & 6.33 & 7.42 & 3.58 & 3.45 & 3.51 \\
\hline $1970-1979$ & 4.65 & 5.79 & 8.82 & 2.75 & 3.16 & 3.31 \\
\hline 1980-1989 & 6.70 & 5.39 & 5.26 & 3.43 & 3.06 & 2.83 \\
\hline $1990-1998$ & 10.26 & 7.98 & 8.27 & 4.65 & 4.21 & 4.47 \\
\hline 1994-1998 & 11.38 & 8.74 & 9.01 & 5.36 & 4.67 & 4.88 \\
\hline 1996-1998 & 12.13 & 9.24 & 10.56 & 5.46 & 4.93 & 5.17 \\
\hline \multicolumn{7}{|c|}{ B. Fixed-composition portfolio income growth rate } \\
\hline 1990 & 0.101 & 0.081 & 0.094 & 0.055 & -0.066 & 0.005 \\
\hline 1991 & 0.076 & 0.009 & 0.038 & -0.045 & 0.044 & -0.145 \\
\hline 1992 & 0.099 & 0.091 & 0.076 & 0.101 & 0.095 & 0.033 \\
\hline 1993 & 0.268 & 0.123 & 0.050 & 0.142 & 0.165 & 0.086 \\
\hline 1994 & 0.207 & 0.135 & 0.152 & 0.183 & 0.134 & 0.120 \\
\hline 1995 & 0.227 & 0.185 & 0.141 & 0.172 & 0.176 & 0.138 \\
\hline 1996 & 0.159 & 0.102 & 0.055 & 0.114 & 0.057 & 0.111 \\
\hline 1997 & 0.222 & 0.161 & 0.139 & 0.209 & 0.135 & 0.142 \\
\hline 1998 & 0.187 & 0.142 & 0.097 & 0.176 & 0.037 & 0.039 \\
\hline $1970-1998$ & 0.138 & 0.115 & 0.106 & 0.125 & 0.095 & 0.071 \\
\hline 1970-1979 & 0.136 & 0.134 & 0.140 & 0.143 & 0.116 & 0.105 \\
\hline 1980-1989 & 0.111 & 0.099 & 0.084 & 0.112 & 0.084 & 0.051 \\
\hline $1990-1998$ & 0.170 & 0.113 & 0.093 & 0.120 & 0.084 & 0.055 \\
\hline 1994-1998 & 0.200 & 0.145 & 0.116 & 0.170 & 0.107 & 0.109 \\
\hline 1996-1998 & 0.189 & 0.135 & 0.096 & 0.166 & 0.076 & 0.096 \\
\hline \multicolumn{7}{|c|}{ C. Varying-composition portfolio income growth rate } \\
\hline 1990 & 0.010 & -0.041 & 0.132 & 0.083 & 0.056 & 0.063 \\
\hline 1991 & 0.038 & 0.076 & 0.136 & 0.077 & 0.152 & -0.155 \\
\hline 1992 & -0.149 & -0.059 & 0.054 & 0.159 & 0.163 & 0.044 \\
\hline 1993 & 0.253 & 0.131 & 0.012 & 0.100 & 0.079 & 0.171 \\
\hline 1994 & 0.078 & 0.082 & 0.269 & 0.046 & 0.108 & 0.117 \\
\hline 1995 & 0.068 & 0.187 & 0.122 & 0.202 & 0.175 & 0.235 \\
\hline 1996 & 0.112 & 0.098 & -0.024 & 0.168 & 0.125 & 0.206 \\
\hline 1997 & 0.089 & 0.071 & 0.053 & 0.225 & 0.131 & 0.217 \\
\hline 1998 & -0.041 & 0.092 & 0.120 & 0.295 & 0.122 & -0.043 \\
\hline $1970-1998$ & 0.092 & 0.112 & 0.100 & 0.173 & 0.139 & 0.127 \\
\hline $1970-1979$ & 0.154 & 0.137 & 0.119 & 0.220 & 0.155 & 0.158 \\
\hline 1980-1989 & 0.074 & 0.128 & 0.086 & 0.149 & 0.137 & 0.132 \\
\hline 1990-1998 & 0.046 & 0.068 & 0.094 & 0.148 & 0.123 & 0.088 \\
\hline 1994-1998 & 0.060 & 0.105 & 0.104 & 0.184 & 0.132 & 0.141 \\
\hline 1996-1998 & 0.051 & 0.087 & 0.048 & 0.228 & 0.126 & 0.120 \\
\hline
\end{tabular}


that the superior performance of growth stocks in the late 1990s was mainly due to investors' rosy expectation about the future growth of technology companies, rather than a change in fundamentals. For this to be true, there should have then been a subsequent price adjustment for both value and growth stocks to reflect their earnings growth. Indeed, in Table 6 we can see that in 2000, the Russell Top 200 Growth Index fell by $24.51 \%$, followed by a decline of $20.5 \%$ the next year. On the other hand, the Russell 2000 Value Index rose by 22.82\% and 14.02\%, respectively. This indicates that investors finally realized that those "growth" companies had fallen short of their expectations, and a price adjustment occurred as a result. Looking at the overall record, from 1979 to 2002, the geometric return of value stocks still outperformed growth stocks. From Table 6, it was $13.99 \%$ vs. $11.57 \%$ for largecap stocks, and $14.74 \%$ vs. $8.94 \%$ for small-cap stocks.

There were some discrepancies in the Russell index, however, as it did not represent extreme bets on growth or value since only two portfolios were formed (instead of 10). Further, the underlying stocks were value weighted and rely on only two indicators (BV/MV and analysts' long-term growth forecasts). To address this concern, Chan and Lakonishok [8] performed another analysis by sorting stocks using a composite indicator and placing them in 10 deciles with each stocks equally weighted in each portfolio. The results are shown in Table 4. From 1996-2001, we can see that for large-cap stocks (Panel A), the value portfolio only fell behind the growth portfolio in 1998 and 1999, and caught up again in 2000 and 2001. As a result, the geometric return for value stocks from $1990-2001$ is $16.1 \%$, compared to $3.8 \%$ for growth stocks. For small cap stocks, the spread is even more significant: $18.4 \%$ for value compared to $-6.2 \%$ for growth.

\section{Conclusions}

Various studies provided evidence that value stocks could generate superior return than growth stocks. This spread is often more significant in the small-cap stocks than in the large-cap stocks, indicating that part of the spread must be attributed to size of the companies. In addition, the studies showed that systematic risk cannot not be accounted for the spread as both glamour and value portfolios have similar beta.

Further studies showed that even we took the companies' size into account, the spread still existed. This leads to the assertion there is a value premium that contributes to the spread. The reasons of the existence of value premium will be explored later. But in a vague sense, some scholars argued that this could be caused by extrapolation bias: people incorrectly use past data to predict future performance of a company.
In addition, a number of different indicators could be used to yield value premium. And a combination of such indicators could often yield a higher return than using just a single indicator.

On the other hand, the persisting superior return of growth stocks in late 1990s seemed to invalidate the claim of value premium. However, further study showed that those "growth" companies didn't realize any stronger subsequent earnings growth than value companies even though their P/I ratio continued to be high. There was also a rigorous price adjustment in late 2000 and 2001, with value stocks skyrocketing and growth stocks plummeting. Combining these two pieces of evidence, some scholars argued that the value premium did not disappear. Instead, it just took longer for the price reversion to occur as market persisted to have rosy expectation to technology companies.

\section{References}

[1] B. Graham and D. Dodd, "Security Analysis," 6th Edition, Graw-Hill, New York City, 2009, pp. 61-70.

[2] S. Basu, "Investment Performance of Common Stocks in Relation to Their Price-Earnings Ratios: A Test of the Efficient Market Hypothesis,” Journal of Finance, Vol. 32, No. 3, 1977, pp. 255-274. doi:10.2307/2326304

[3] E. F. Fama and K. R. French, "The Cross-Section of Expected Stock Returns,” Journal of Finance, Vol. 47, No. 2, 1992, pp. 427-465. doi:10.2307/2329112

[4] J. Lakonishok, A. Shleifer and R. W. Vishny, "Contrarian Investment, Extrapolation, and Risk,” Journal of Finance, Vol. 49, No. 5, 1994, pp. 1541-1578. doi:10.2307/2329262

[5] L. K. C. Chan, Y. Hamao, and J. Lakonishok, "Fundamentals of Stock Return in Japan," Journal of Finance, Vol. 46, No. 5, 1991, pp. 1739-1764. doi:10.2307/2328571

[6] E. F. Fama and K. R. French. "Value versus Growth: The International Evidence,” Journal of Finance, Vol. 53, No. 6, 1998, pp. 1975-1999. doi:10.1111/0022-1082.00080

[7] R. W. Banz, "The Relationship between Return and Market Value of Common Stock," Journal of Financial Economics, Vol. 9, No. 1, 1981, pp. 3-18. doi:10.1016/0304-405X(81)90018-0

[8] L. K. C. Chan and J. Lakonishok, "Value and Growth Investing: Review and Update," Financial Analyst Journal, Vol. 60, No. 1, 2004, pp. 71-86. doi:10.2469/faj.v60.n1.2593

[9] C. Asness, "The Interaction of Value and Momentum Strategies,” Financial Analysts Journal, Vol. 53, No. 2 1997, pp. 29-36. doi:10.2469/faj.v53.n2.2069

[10] D. Kent and S. Titman, "Market Efficiency in an Irrational World,” Financial Analysts Journal, Vol. 55, No. 6 1999, pp. 28-40. doi:10.2469/faj.v55.n6.2312 
[11] L. K. C. Chan, J. Lakonishok and T. Sougiannis, "The Stock Market Valuation of Research and Development Expenditures,” Journal of Finance, Vol. 56, No. 6, 2001. pp. 2431-2456. doi:10.1111/0022-1082.00411

[12] J. Piotroski, "Value Investing: The Use of Historical Financial Statement Information to Separate Winners from
Losers,” Journal of Accounting Research, Vol. 38, 2000, pp. 1-41. doi:10.2307/2672906

[13] L. K. C. Chan, J. Karceski and J. Lakonishok, "New Paradigm or Same Old Hype in Equity Investing?” Financial Analysts Journal, Vol. 56, No. 4, 2000, pp. 23-36. doi:10.2469/faj.v56.n4.2371 